Magdalena KUGIEJKO

Uniwersytet im. Adama Mickiewicza w Poznaniu

\title{
BADANIA NAD BIOGRAFIĄ TURYSTYCZNĄ STUDENTÓW V ROKU KIERUNKU „TURYSTYKA I REKREACJA" UNIWERSYTETU IM. ADAMA MICKIEWICZA W POZNANIU
}

\section{Wprowadzenie w problematykę badawczą}

Współczesna dynamika, przemiany świata mają bezpośredni wpływ na zmiany, jakie zachodzą w szeroko rozumianym doświadczeniu turystyczno-podróżniczym. Zmiany te powodują również, że coraz częściej zapomina się o tym, co ukształtowało pierwsze indywidualne wyjazdy.

Każdy etap cyklu życia człowieka cechuje się innymi potrzebami rekreacyjnymi i innymi ograniczeniami związanymi z wyjazdami. Celem niniejszego opracowana jest identyfikacja świadomości podjęcia podróży (aktywności turystycznej) podczas edukacji, określona w grupie studentów V roku kierunku "turystyka i rekreacja”. Uznano, że jest to najlepszy sposób, aby sprawdzić, w jakim stopniu wyrażane są indywidualne cechy, następuj ingerencja osób trzecich, czy wpływa działalność placówek wychowawczych (szkół). Praca, poza wprowadzeniem, składa się z czterech rozdziałów. W pierwszym przedstawiono przesłanki do podjęcia badan, drugi zawiera przegląd dotychczasowych badań nad aktywnością turystyczną i metodą biograficzną, w kolejnej części przybliżono metodykę badań empirycznych oraz wskazano główne rezultaty poznawcze, a ostatni rozdział zawiera podsumowanie badań oraz przedstawienie ich dalszych kierunków. 


\section{Zakres i cel pracy}

Celem opracowania autorki jest prezentacja pilotażowych wyników badań dotyczących biografii aktywności turystycznej studentów II roku studiów magisterskich kierunku "turystyka i rekreacja” na Wydziale Nauk Geograficznych i Geologicznych Uniwersytetu im. Adama Mickiewicza w Poznaniu. Na użytek niniejszego opracowania skonstruowany został kwestionariusz retrospektywnej ankiety. Pytania stworzyły pewien kanon ukierunkowany tematycznie; metoda biograficzna (KACZMAREK 2004) używana analogicznie, biografia turystyczna. Do badań wybrano celową próbę, $\mathrm{w}$ dużej mierze jest ona uzasadniona jakościowym charakterem badań. Warto nadmienić, że w naukach społecznych często korzysta się z prób nielosowych (FRANKFORT-NACHMIAS, NACHMIAS 2001). Postępując za pracą J. KACZMARKA (2004) można stwierdzić, że badania biograficzne posiadają najdłuższą tradycję $\mathrm{w}$ środowisku socjologicznym, natomiast $\mathrm{w}$ naukach geograficznych stosowane są rzadko. Metoda stwarza najlepsze możliwości poznania, poprzez retrospekcję czasową zdarzeń zarówno jednostki (studenta), jak i całej grupy (rocznik, dany kierunek). Metoda biograficzna $\mathrm{w}$ najszerszym jej rozumieniu, to analiza przebiegu życia jednostki, ujęta z określonego punktu widzenia: indywidualnego, społecznego, zawodowego itd. (HELLING 1990, STASIAKIEWICZ 1999). Odwołanie się do subiektywnej perspektywy respondenta, obiera jej własny punkt widzenia za niezbędny punkt wyjścia do konstruowania uogólnień teoretycznych (WŁODAREK, ZIÓŁKOWSKI 1990). J. KACZMAREK i in. (2002) zdefiniowali biografię turystyczną jako drogę życiową człowieka przez „zbiór miejsc, które są odwiedzane z przyczyn innych niż podejmowanie pracy i nauki, lub osiedlanie się na stałe". Materiały biograficzne uzyskane zarówno drogą pośrednią, jak i bezpośrednią, podobnie jak sama metoda, są przedmiotem wielu kontrowersji. Do najczęstszych zarzutów należy m.in. brak obiektywizmu, upraszczanie rzeczywistości, czy jej deformowanie wynikające z niedostatków pamięci lub skłonności do zapominania przykrych zdarzeń (KACZMAREK 2005). Dlatego bardzo ważna jest ocena zawartości zebranych materiałów, wyważenie ich wartości i przydatności. Jednocześnie zalety tej metody, takie jak możliwość pokazania procesów przemian świadomości czy aktywności człowieka, powodują, że nie jest ona zarzucana, wręcz przeciwnie, przeżywa współcześnie renesans, m.in. seminaria biograficzne organizowane w Instytucie Socjologii Uniwersytetu Łódzkiego (KOWALCZYK-ANIOŁ 2013). 


\section{Aktywność turystyczna badanej grupy}

Istnieje wiele definicji aktywności turystycznej (MEDLIK 1995, WŁODARCZYK 1999), gdzie najczęściej rozpatrywane są dwa spektra określane przez B. WŁODARCZYKA (1999) jako aktywność turystyczna sensu stricto oraz aktywność turystyczna sensu largo. W odniesieniu do wyjazdów turystycznych jest to proces zaczynający się zanim nastąpi wyjazd oraz trwający jeszcze po powrocie (ALEJZIAK 2009). Podejmowana aktywność turystyczna i rekreacyjna człowieka jest konsekwencją decyzji o zmianie miejsca i czasu. Na takie działania wpływa w różnym stopniu i z różną siłą zachowanie człowieka (KRZYMOWSKA-KOSTROWICKA 1997). Mowa tu o czynnikach; endogenicznych i egzogenicznych, jakie wzajemnie na siebie oddziałują kształtując osobowość ludzką (rys. 1). Spośród wyróżnionych elementów ważne dla dalszej analizy są uwarunkowania społeczne (egzogeniczne - socjokulturowe; społeczne i informacyjno-edukacyjne).

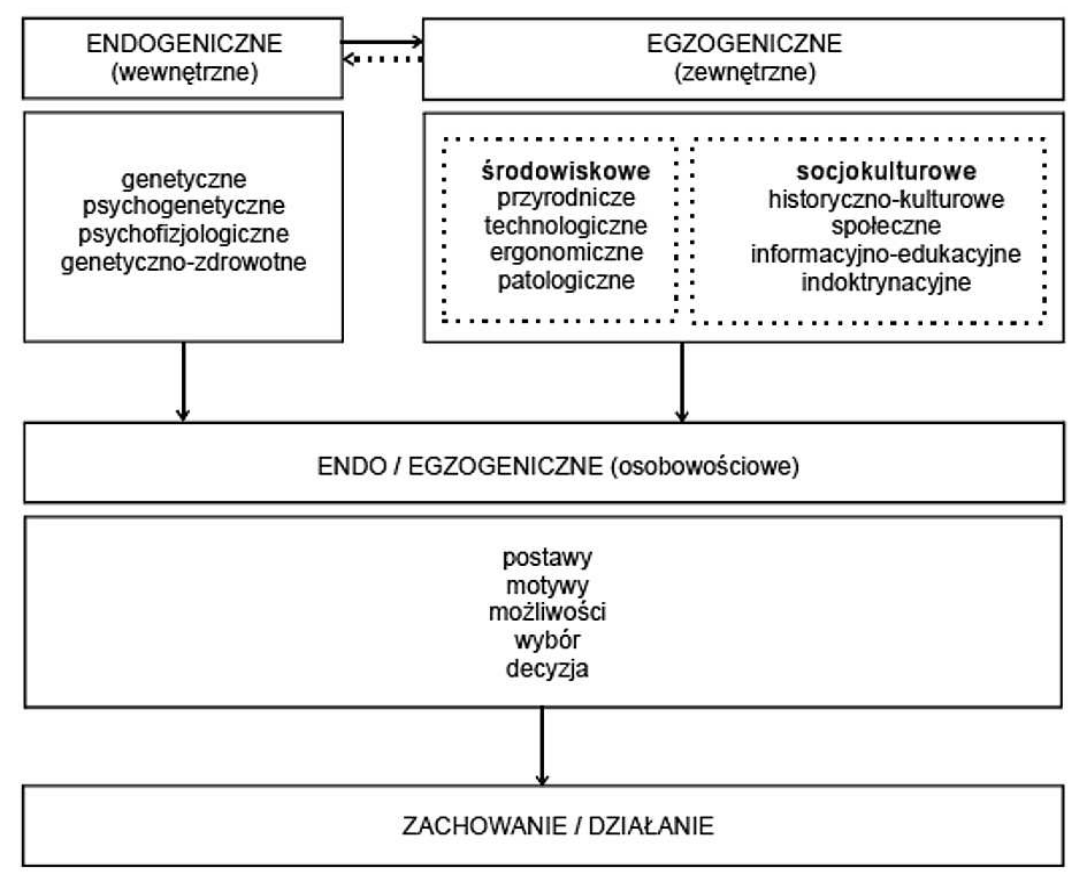

Rys. 1. Czynniki warunkujące zachowania ludzkie

Źródło: A. KRZYMOWSKA-KOSTROWICKA (1997) 
Według A. KRZYMOWSKIEJ-KOSTROWICKIEJ (1997) uwarunkowania społeczne $\mathrm{w}$ istotnym stopniu decydują o strukturze, charakterze i trwałości zachowań turystyczno-rekreacyjnych człowieka. Autorka wskazała na opinie większej grupy (np. oddział szkolny, grupa ćwiczeniowa na studiach) i ich sposoby zachowań, które decydują o postawach i decyzjach jednostki. Taką grupą w początkowym okresie życia jest rodzina, potem nauczyciele i grupa rówieśników. Przedstawiony rys. 2 (za RAPAPORT, RAPOPORT 1975) obejmuje wszelkie wpływy, jakim podlega człowiek oraz jasno prezentuje najważniejsze role społeczne.

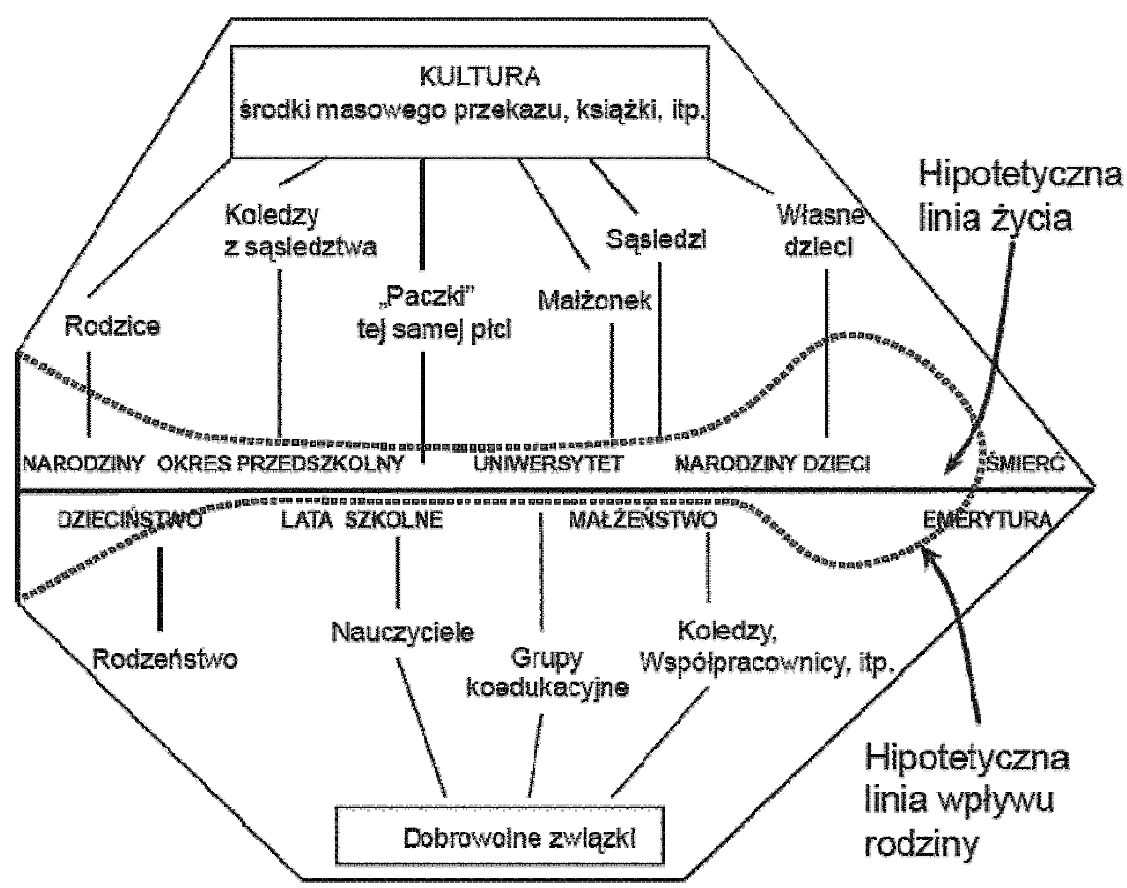

Rys. 2. Wpływ cyklu życiowego na rekreacyjne zachowania według R. i R. RAPAPORT (1975)

Źródło: D.J. Walmsley, G.J. Lewis (1997) cyt. za: J. KOWALCZYK-ANIO૯ (2007)

Każdy etap życia zwiększa lub zmniejsza potrzeby rekreacyjne, na co mają wpływ różnego typu ograniczenia (czasowe, przestrzenne, finansowe itp.). Wyjazdy urlopowe, aktywność turystyczna człowieka podlegają zmianom w kolejnych fazach życia. 


\section{Postępowanie badawcze i wyniki}

Badania przeprowadzono w marcu i kwietniu 2013 r. wśród 66 respondentów studiów stacjonarnych, którzy stanowią 65\% ogółu studentów na roku. Podkreślono celowy dobór oraz to, że każda grupa studentów posiada indywidualne cechy. Wśród respondentów przeważały kobiety, które stanowiły $67 \%$. Struktura wieku wynika ze specyfiki badanej grupy, zdecydowaną większość stanowią osoby w wieku 24-25 lat. Ankietowani to osoby średnio zamożne, których duży odsetek korzysta z pomocy rodziców. Dodatkowo aż 45 studentów podejmuje pracę dorywczą, kilkoro (6 osób) zgłaszało pracę na pełny etat. Biorąc pod uwagę miejsca pochodzenia studentów i uczęszczania do poszczególnych szkół można stwierdzić, że $64 \%$ z nich w trakcie edukacji wczesnoszkolnej, gimnazjalnej i ponadgimnazjalnej uczyło się w szkołach miejskich, natomiast 36\% studentów w szkołach wiejskich. Wśród respondentów 88\% kontynuuje studia na wybranym kierunku „turystyka i rekreacja", 3\% skończyło inny kierunek na Wydziale Nauk Geograficznych i Geologicznych w Poznaniu, a 9\% przeniosło się z innych ośrodków w Polsce. W grupie badanych sześć osób studiuje równocześnie dodatkowy kierunek.

Respondenci zostali poproszeni o opisanie podejmowanej aktywności turystycznej - wyjazdów od momentu rozpoczęcia edukacji szkolnej. Wypowiedzi uporządkowano według schematu, w którym każde z pytań odnosiło się do poszczególnych etapów nauki: miejsce zamieszkania - miejsca wyjazdów - grupa, towarzysz podróży - decyzja o kierunku studiów - częstotliwość wyjazdów - bodźce zewnętrzne - plany na przyszłość.

W opracowaniu głównie skupiono się na początkowych stadiach, obejmując zasięgiem okres dzieciństwa, szkoły i nauki na uczelni. Dzięki uzyskanemu materiałowi można też $\mathrm{w}$ dalszych badaniach przyjrzeć się prognozom, które poprzez analizę biografii wcześniejszych wyjazdów mogą wskazać na pewne tendencje aktywności turystycznej. Metoda wykorzystana została jako jeden ze środków do analizy konkretnego problemu - analizy zdarzeń życiowych. W świetle takich wniosków również, pojawia się pytanie, jak znaczący jest wpływ nabytych w dzieciństwie doświadczeń na późniejsze decyzje w doborze oraz częstotliwości wyjazdów.

Pierwsze wyjazdy najczęściej inicjowane były przez rodziców - to oni są uznawani za prekursorów działań w życiu swoich dzieci. W momencie rozpoczęcia edukacji dodatkowym bodźcem do udziału w wyjazdach staje się szkoła, rówieśnicy. Zaprezentowane na rys. 3 zestawienie obrazuje to, 
jakie czynniki wpływały na wybory badanych respondentów. Początkowy kontakt $\mathrm{z}$ podróżami ściśle powiązany był $\mathrm{z}$ działaniem najbliższego otoczenia domowego oraz placówki edukacyjnej. Liczne wyjazdy wakacyjne organizowane są przez rodzinę, często również skupiają się na odwiedzinach krewnych. $\mathrm{W}$ miarę dorastania i podjęcia nauki $\mathrm{w}$ gimnazjum aktywność obu bodźców spada (zmniejszenie o $25 \%$ roli rodziców oraz o 18\% wpływu szkoły). Pojawia się kolejny element, jakim są organizacje środowiskowe. Respondenci zwracają uwagę, że w tym czasie brali udział w wyjazdach zorganizowanych typu: kolonie, obozy itp. Największy spadek znaczenia współuczestnictwa w wyjeździe mają rodzice i organizacje zewnętrzne; relatywnie dość często wskazywano na działalność szkoły.

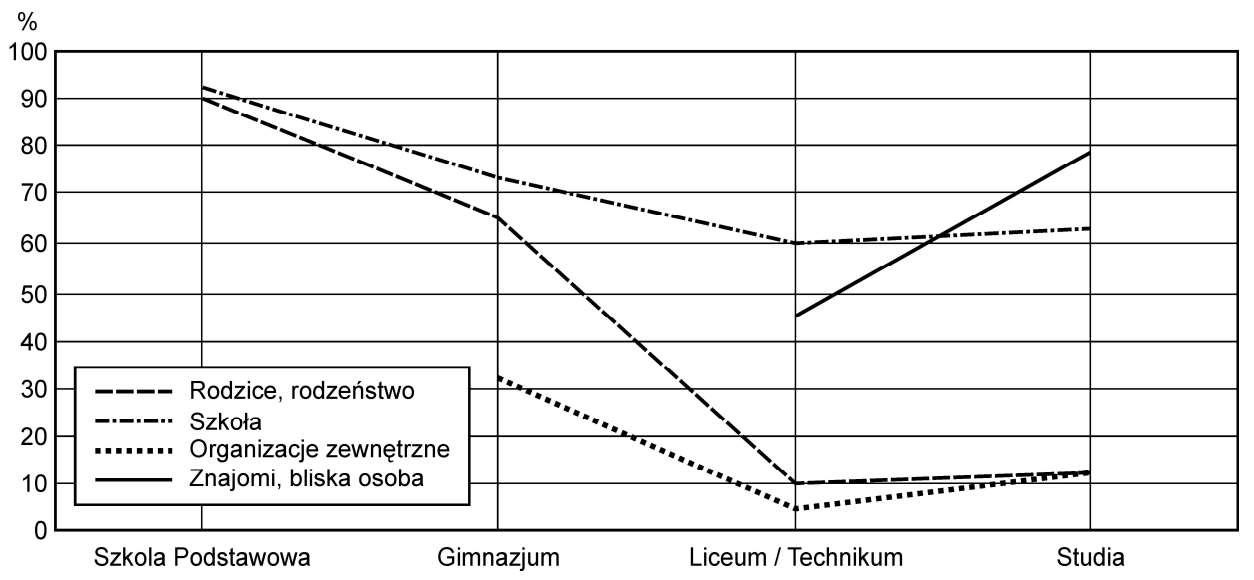

Rys. 3. Organizatorzy wyjazdów turystycznych ankietowanych studentów Źródło: opracowanie własne

Ankietowani z upływem lat świadomie zauważają istotne oddziaływanie podstawowego czynnika ograniczającego wspólne rodzinne wyjazdy, jaki stanowią koszty ponoszone na pobyt wakacyjny. Niekiedy przewyższały one domowy budżet, dlatego rodzice wysyłali dzieci na różnego typu wycieczki i obozy, żeby miały możliwość opuszczenia miejsca zamieszkania i spędzenia czasu wolnego w atrakcyjnej destynacji turystycznej. Odwołując się do cyklu życia i zmian w okresie tzw. młodzieńczego buntu (OLESZKOWICZ 2006) trzeba stwierdzić, że w latach dorastania znacząco spada wpływ rodziców, rodziny na decyzje młodzieży. W miejsce wcześniejszych prekursorów, inicjatorów i organizatorów pojawiają się nowi, którymi często są rówieśnicy, sympatie, grono przyjaciół. W okresie dorastania wyjazdy orga- 
nizowane są $w$ dużej mierze indywidualnie i obejmują teren najbliższej okolicy zamieszkania oraz obszar kraju. Przy wspomnianych zmianach zachodzących w środowisku rodzinnym (55\%) interesująca jest nadal wysoka pozycja szkoły, która zmniejszyła się zaledwie o $14 \%$. W okresie pomiędzy nauką $\mathrm{w}$ szkole ponadgimnazjalnej a podjęciem studiów rola rodziny jest stabilna, zwiększa się liczba wyjazdów z gronem znajomych (35\%), jak również korzystanie z usług organizatorów turystyki (6\%). Wzrost zainteresowania pośrednikami $\mathrm{w}$ organizacji podróży związany jest $\mathrm{z}$ wyjazdami zagranicznymi - korzystaniem z przelotów, bazy noclegowej, a nawet z wykupywaniem całych pakietów turystycznych.

Zanotowano też dużą skłonność osób, które zostały wychowane w tradycji samodzielnego organizowania wypoczynku do jej kontynuacji. Respondenci podkreślają również to, że w podróżach i ich osobistym przygotowaniu niezbędna była specjalistyczna wiedza pozyskana na studiach - na kierunku "turystyka i rekreacja”. Z badań nad turystyką Polaków wynika m.in. trend wzrostu aktywności turystycznej oraz to, że zwraca się uwagę na zróżnicowanie grup wiekowych i społecznych. Największy wskaźnik wyjazdów charakteryzuje młodzież, osoby zamożne, reprezentanci takich grup zawodowych jak lekarze, prawnicy (GUS, Warszawa 2013, COBOS 2013). $Z$ relacji badanych wynika, że koszty, jakie pochłaniają podróże są dla nich sporym obciążeniem i często muszą rezygnować z wyjazdów na rzecz podjęcia pracy. Początek kariery zawodowej stał się główną przyczyną nieuczestniczenia w podróżach lub, jeśli mają one miejsce, są krótkie i niskobudżetowe. W nawiązaniu do kierunku podejmowanych studiów zapytano respondentów o motyw jego wyboru (rys. 4). Przedstawione na rys. 4. odpowiedzi podkreślają zasadność rozbudzenia zainteresowań podróżami od najmłodszych lat. Studenci, którzy uczestniczyli w wyjazdach rodzinnych, szkolnych czy też w wyjazdach kolonijnych zwracali uwagę na to, że chcą dalej kontynuować eksplorację świata, nie tylko najbliższej okolicy, ale spełniać marzenia o najodleglejszych zakątkach na Ziemi (Australia, Indie). Podjęcie studiów dla części z nich $(15 \%)$ miało rozwinąć ich umiejętności w zakresie turystyki, poznania nowych kultur i przygotowania do przyszłego zawodu w turystyce.

Wybierane $\mathrm{w}$ szkołach gimnazjalnych i ponadgimnazjalnych profile turystyczne, a także wcześniejsze wyjazdy miały również znaczenie dla kontynuacji edukacji o tematyce turystycznej. Wśród respondentów tylko 5\% potwierdziło, że podjęty kierunek studiów wynikał z nieprzyjęcia ich w pierwszym naborze na inną specjalizację czy kierunek. Według autorki 


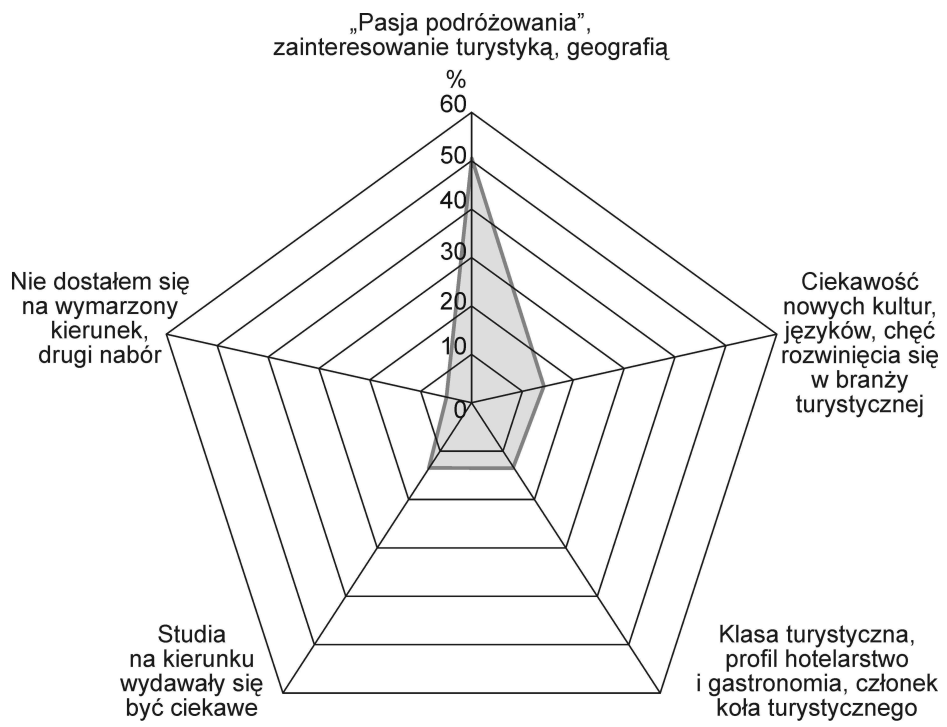

Rys. 4. Zestawienie motywów wyboru przez respondentów kierunku studiów "turystyka i rekreacja”

Źródło: opracowanie własne

jest to jedno z kluczowych pytań, które obrazuje to, co skłania młodzież do podjęcia dalszej ukierunkowanej nauki, co jest dla nich interesujące i czego oczekują po ich zakończeniu. Trzeba zwrócić uwagę na ofertę dydaktyczną, aby kierunek oprócz rozwijania zainteresowań, dawał umiejętności do podjęcia pracy w sektorze turystyki.

\section{Podsumowanie}

Biografia urlopowo-wakacyjna oparta na badaniach ankietowych daje duże możliwości zarówno na poziomie rejestracji zjawiska, oceny jego różnorodności (gromadzony materiał), jak i na późniejszym etapie - interpretacji. Niewątpliwą zaletą metody jest szansa na rzadko stosowane w geografii turyzmu dynamiczne pokazanie zjawiska w odniesieniu do tej samej grupy ankietowanych. Oprócz określenia zasięgu geograficznego stwarza możliwość badania przez pryzmat biografii wybranego zagadnienia społecznego (np. cyklu życia człowieka i rodziny, „wychowania” do turystyki). Oczywiście metoda ta, jak każda, ma swoje słabe strony. Część z nich wynika z charakteru samych badań biograficznych (np. wspominana wcześniej subiektyw- 
ność treści), inne m.in. z konieczności generalizacji danych, uciążliwości prowadzenia badań terenowych (czasochłonność). Metoda ta daje także badaczowi dużą satysfakcję w poznawaniu świata oraz skłania do refleksji nad własną biografią, także turystyczną (KOWALCZYK-ANIOŁ 2013). W realizacji celu pracy zwrócono uwage szczególnie na wydzielone przedziały czasowe i określenie związków pomiędzy nimi.

Uwzględniając fazy cyklu życia człowieka, dokonano podstawowej analizy zachowań aktywności turystycznej. Stopień aktywności i częstotliwość wyjazdów są w dużej mierze uzależnione od możliwości finansowych oraz etapu życia. Elementem odniesienia, była szkoła, a następnie rodzina. Te dwa środowiska najczęściej wymieniane były jako inicjatorzy i organizatorzy wyjazdów oraz miały największe oddziaływanie na wybory dalszych podróży.

Poprzez coraz łatwiejszą realną "dostępność świata”, a także dzięki Internetowi młodzi ludzie stają się bardziej samodzielni, otwarci na to, co odległe i nieznane. Badaną grupę cechowała duża ciekawość świata. Wybór kierunku "turystyka i rekreacja” miał umożliwić im częstsze wyjazdy i zgłębianie swojej wiedzy na temat nowych miejsc (kultura, atrakcje turystyczne, kuchnia). Następnie (ukierunkowani) respondenci sami stali się organizatorami, sporadycznie korzystając z pomocy wykwalifikowanych touroperatorów. Największym utrudnieniem, na jakie studenci zwracali uwagę, był brak środków finansowych, praca i ogólny brak wolnego czasu na wyjazdy.

Ważnym aspektem jest to, żeby sprostać wymaganiom określanym przez wiek uczestników wyjazdu turystycznego, a także zasygnalizować istotność odpowiedniego przygotowania formy i miejsca wycieczki oraz zwrócić uwagę na zmiany w różnorodności tematycznej, sposobie organizacji i specyfice grup podróżujących.

Powyższe badania są początkowym etapem, podczas którego pojawiło się kilka nowych problemów badawczych dotyczących obszarów recepcyjnych młodzieży akademickiej. Skłania to do podjęcia kolejnych prób określenia biografii turystycznej badanej zbiorowości, poszerzając próbę o nowe grupy badawcze i przestrzeń eksploracji.

\section{Bibliografia}

AlEJZIAK W., 2009, Determinanty i zróżnicowanie społeczne aktywności turystycznej, Wyd. Akademii Wychowania Fizycznego im. Bronisława Czecha, Kraków, s. 17-18.

RANKRORT-NACHMIAS Ch., NACHMIAS D., 2001, Metody badawcze w naukach spotecznych, Wyd. Zysk i S-ka, Poznań. 
GUS. Program badań statystycznych statystyki publicznej na rok 2014; Warszawa, sierpień 2013 r. załącznik do rozporządzenia Rady Ministrów z dnia 9 sierpnia 2013 r. (Dz. U. z 2013 r., poz. 1159).

HELLING I.K., 1990, Metoda badań biograficznych, [w:] J. Włodarek, M. Ziółkowski, Metoda biograficzna w socjologii, PWN, Warszawa-Poznań.

KACZMAREK J., 2004, Geobiografia - historie życia a studia nad migracjami, "Acta Universitatis Lodziensis, Folia Geographica Socjo-Oeconomica", 5.

KOWALCZYK-ANIOŁ J., 2007, Rozwój przestrzeni urlopowo-wakacyjnej rodzin studentów Uniwersytetu Łódzkiego, Łódzkie Towarzystwo Naukowe, Łódź.

KOWALCZYK-ANIOє J., 2013, Wykorzystanie biografii urlopowo-wakacyjnej w badaniach przestrzeni turystycznej w ujęciu pokoleniowym, ,Turyzm/Tourism”, 23, 2.

KRZYMOWSKA-KOSTROWICKA A., 1997, Geoekologia turystyki i wypoczynku, PWN, Warszawa.

LIPIEC J., 2002, U podstaw teorii turystyki, „Wychowanie Fizyczne i Zdrowotne”, 1 (412).

MEDLIK S., 1995, Leksykon podróży, turystyki i hotelarstwa, PWN, Warszawa.

OlesZKOWICZA., 2006, Bunt młodzieńczy. Uwarunkowania. Formy. Skutki, Wyd. Naukowe Scholar, Poznań.

RAPAPORT R., RAPAPORT R., 1975, Leisure and the Family Life Cycle, Henley.

STASIAKIEWICZ M., 1999, Twórczość i interakcja, Wyd. Naukowe UAM, Poznań.

SZCZEPAŃSKI J., 1971, Metoda biograficzna, [w:] J. Szczepański, Odmiany czasu teraźniejszego, Warszawa.

WŁODARCZYK B., 1999, Przemiany form aktywności turystycznej - przykład krawędzi Wyżyny Łódzkiej, ser. „Szlakami Nauki”, nr 27, Łódzkie Towarzystwo Naukowe, Łódź.

WŁODAREK J., ZIÓŁKOWSKI M., 1990, Metoda biograficzna w socjologii, PWN, Poznań-Warszawa. 